\title{
ANALYSIS OF THE COMPONENTS OF SOCIAL AND ECONOMIC SECURITY AND THE PLACE OF PROTECTIONISM IN ITS PROVISION
}

\author{
CShvaiba D., ORCID: 0000-0001-6783-9765; Ph.D., Belarusian Trade Union \\ of Workers of Chemical, Mining and Oil Industries; Belarusian National Technical University, \\ Minsk,Belarus,shvabia@tut.by
}

\section{АНАЛИЗ СОСТАВЛЯЮЩИХ СОЦИАЛЬНО-ЭКОНОМИЧЕСКОЙ БЕЗОПАСНОСТИ И МЕСТО ПРОТЕКЦИОНИЗМА В ЕЕ ОБЕСПЕЧЕНИИ}

\author{
СШвайба Д. Н., ORCID: 0000-0001-6783-9765; канд. экон. наук, \\ Белорусский профсоюз работников химической, горной и нефтяной отраслей \\ промышленности; Белорусский национальный технический университет, \\ 2. Минск, Беларусь, shvabia@tut.by
}

Abstract. In the socio-economic security of the country it is possible to note 3 main parts: financial and economic freedom, which, taking into account the state of the global economy, is not absolute; strength and stability of the state economy, which includes the protection of property in all its forms, the formation of stable conditions for entrepreneurship, etc.; the ability to progress and self-develop, which is very important in the modern world. For economic entities, the forecast of social and economic security is all the more necessary, because their potential is the defining moment of anti-crisis formation and the guarantor of the financial and economic recovery of the state.

Аннотащия. В социально-экономической безопасности страны возможно отметить 3 основные части: финансово-экономическая свобода, которая, беря во внимание состояние глобальной экономики, не абсолютна; прочность и стабильность экономики государства, что включает в себя защиту собственности во всех ее формах, образование стабильных условий для предпринимательства и т. д.; умение прогрессировать и саморазвиваться, что очень принципиально в современном мире. Для хозяйствующих субъектов прогноз социальноэкономической безопасности тем более нужен, т. к. их потенциал есть определяющий момент антикризисного становления и гарант финансово-экономического подъема государства.

Keywords: socio-economic security, government, society, enterprise, employee, threat, security, interests, economics, analysis, system.

Ключевые слова: социально-экономическая безопасность, государство, общество, предприятие, работник, угроза, безопасность, интересы, экономика, анализ, система.

Safety acts as a certain order (position) of a complex system, in which the internal and external characteristics interacting with it do not harm the system itself and/or do not allow the progress to stop.

At the moment, there is no universal definition of 'socio-economic security' in the array of definitions. In addition, not paying attention to the need for scientific work, there is a significant drawback. 
Safety subdivided into personal (physical) security, social and state [1, p. 251]. State protection includes protection of geographical (physical) limits, demographic, financial, economic, environmental and internal. The very concept of socio-economic security is considered the sum of the marginal forms of interests of the country, society, economic entity and the individual (Figure 1).

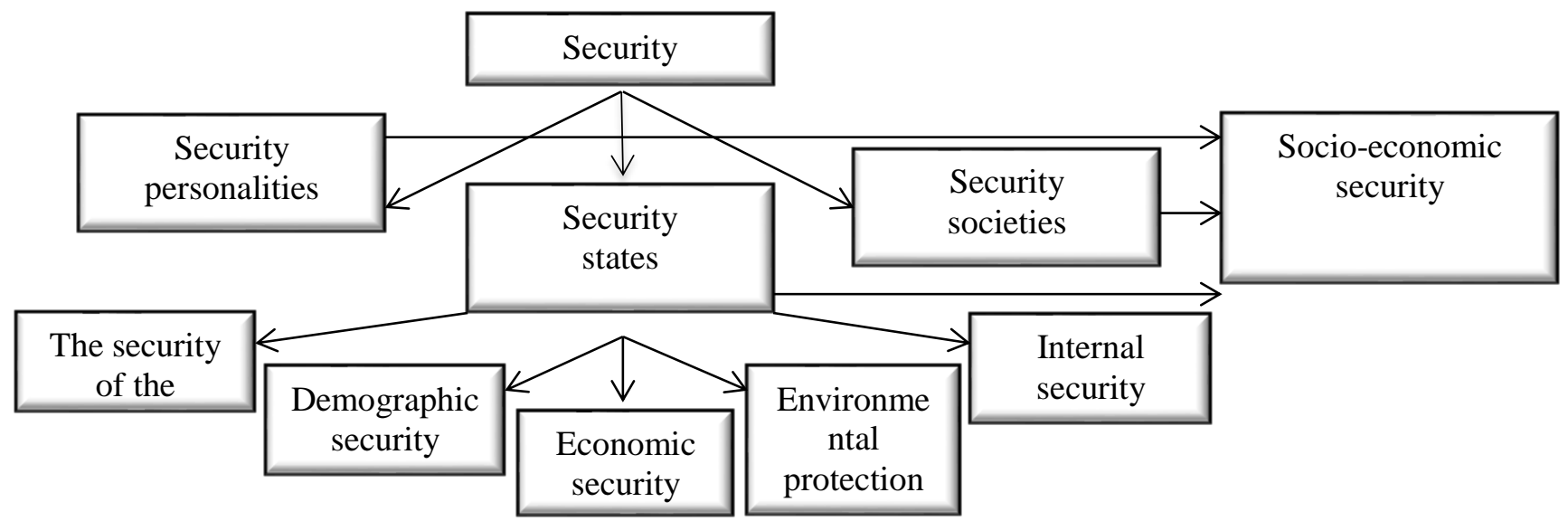

Figure 1. Decomposition of the concept of security. Source: elaboration of author.

Today's idea of socio-economic security was formed in the 30 s of the last centuries in the United States in the framework of only emerging 'economic security'. In the American 'new course' of financial and economic policy (1932-1945) was built emphasis on 'economic security of the individual as a basis for ensuring the financial and economic security of the country and society as a whole' [2, p. 116].

From the point of view of systems theory, the interpretation of socio-economic security reveals a number of formulations, such as:

Socio-economic security is an important qualitative description of the financial and economic system, which determines its ability to support the living conditions of the population and its financial and economic behavior [3, p. 131]. In this case, under the financial and economic behavior in the present case, any case of social behavior is considered. By Definition, G. Sokolova, financial and economic behavior in General - is the behavior associated with the search of financial and economic alternatives for the purpose of reasonable choice, i.e. choice, which minimized loss and risk and maximize a clear advantage [4, p. 22].

Socio-economic security is the situation of the financial-economic system, which is the potential to develop sustainable, efficient and allow public tasks, and in which the country is able to implement independent economic and financial policies [5, p. 773].

Further analysis of the definition of 'socio-economic security' depends on the structure to which it relates. At the macro-level of the economy and the level of the economic entity, the meaning of the definition will be different, and will differ primarily in scope, type and method of protection against danger [6, p.152; 7, p. 1149; 8, p. 7].

\section{Macro level}

Socio-economic security of the state - a state of the economy, providing a sufficient indicator of social existence and intensive development of the country, the stability and sovereignty of its financial and economic interests in relation to the likely internal and external hazards and impacts. For example, in the Republic of Belarus the Ministry of economy monitors 15 most 
important indicators that directly affect the socio-economic security of the state, and in time informs the leaders of the state about the excess of their values [9, p. 8].

See Table 1. some indicators of social development of the state in a comparative context are given.

MAIN INDICATORS OF SOCIAL DEVELOPMENT OF BELARUS

Table 1.

IN THE COMPARATIVE CONTEXT, 2017

(https://clck.ru/FsAAd; http://hdr.undp.org/en/data; https://clck.ru/FsABL)

\begin{tabular}{lccc}
\hline \multicolumn{1}{c}{ Indicators } & Belarus & Neighborhood $^{l}$ & World \\
\hline Human development index & 0,786 & 0,798 & 0,702 \\
Education index & 0,820 & 0,818 & 0,618 \\
Health index & 0,768 & 0,791 & 0,776 \\
Poverty level, \% & $4,0^{2}$ & $15,4^{3}$ & $14,5^{4}$ \\
The level of inequality, the Gini coefficient & 0,265 & 0,332 & - \\
\hline
\end{tabular}

Source: data of the National statistical Committee of the Republic of Belarus, World Bank, UNDP

Note: 1 - Russia, Ukraine, Poland, Lithuania, Latvia. 2 - in the national definition according to official data. 3 - average value in the national definition according to the world Bank. 4 - in the international definition (proportion of the population living on less than \$1.25). U.S. PPP per day.

Proposed data formed our state because of the 'gradualist' [10, p. 26] approaches, in which much attention is paid to the social specificity of financial-economic transformation. Based on this condition, there is an awareness of socio-economic security in the country.

Based on the above, it turns out that socio-economic security is the position of the economic system, which makes it likely to meet the entire array of real financial and economic needs of society, guarantees its financial and economic independence, sustainable development, equal position, reliable protection from internal and external threats and the influence of factors that are difficult to predict [11, p. 157].

At the same time, socio-economic security is a system of protection of the basic interests of society and the country. Objects of defense can be considered: the economic system of the state as a whole or its separate segments, separate spheres of management, physical and legal entities as subjects of economic activity [12, p. 27].

In the scientific literature it is possible to meet the following definition. Socio-economic security is a provision of security of the financial and economic system of the country, which guarantees the necessary level of social and political existence, intensive formation of the country (Association of States) [13].

A number of researchers agree that socio-economic security is not only about the preservation of state interests, but also the willingness and probability of various authorities to form methods of maintaining the socio-political strength of the society [14, p. 258].

In some sources, socio-economic security is seen as the probability of the state economy to ensure the welfare of society and the stability of the domestic market, regardless of the presence of external factors and internal motives [15]. At the same time, state protection is an array of social and state guarantees that ensure reliable formation of the state, protection of basic values and interests, sources of spiritual and material development from internal and external threats [16].

\section{Meso Level}

Socio-economic security of the territory is a system of measures to protect the financial and economic field of the territory from internal and external threats, the functioning of the components 
of the economy of a separate territory: institutional infrastructure (administrative-territorial administration and financial institutions); industrial sector (enterprises); transport infrastructure and communication; science and scientific institutions; life support systems; public sphere [17].

\section{Micro Level}

Socio-economic security of an economic entity is the security of its scientific, technical, technological, production and human resources from direct (active) or indirect (passive) financial and economic dangers. These threats are associated, for example, with inefficient or ineffective scientific and industrial policy of the country or the formation of a negative external environment, as well as the possibility of its reproduction.

Based on the above definitions it is possible to form the following conclusions:

1. The security of any object under study suggests that it is able to solve the existing problems, and in the case of some force majeure events or hazards has the ability to protect the return to initial performance.

2. All definitions of the term 'safety' include the following:

-the presence of hazards, divided into external and internal;

-presence of significant interests of the objects of protection;

-balance of interests between the objects of defense.

3. The study of socio-economic security implies:

-selection of criteria characterizing the position of the system and its significant interests;

-identification of a mechanism to ensure the weighty interests of the system;

-assessment of internal and external hazards;

-identification of criteria and points that lead to the emergence of danger at different levels of the system.

Based on the acquired conclusions, it is possible to speak about socio-economic security as the state of the system of financial and economic relations between economic entities, which guarantees the probability of realization of significant financial and economic interests and the necessary level of their safety from external and internal hazards, taking into account the balance of interests of any of the subjects of relations. This perception of security has the ability to act as a methodological basis for the theoretical justification of both socio-economic security of the country and/or territory, and a separate economic entity.

In the process of studying the essence of socio-economic security from the standpoint of modeling as a method of scientific knowledge, the following interpretation of the leading definitions is proposed.

Objects of socio-economic security-a financial and economic system and its components: natural resources, production and non-production funds, cash resources, economic structures, people, society and other Objects of socio-economic security are considered as an object of modeling.

Subjects of social and economic security - the country, the government and its structures (ministries, departments and others), legislative bodies, economic entities of both the state and private sector of the economy, society as a whole, the individual.

The dangers of socio-economic security are phenomena and processes that have a negative impact on the economy of the state, constraining the financial and economic interests of the individual, society, economic entity and the country are considered as the results of the modification of the external environment, the incorrect formation of the internal environment (in particular, the structure and connections in the system), mismatch of interests. 
Characteristics of socio-economic security are fundamentally important properties that make it possible to assume the state of the financial and economic system as a whole, its strength and mobility-characteristics of the order, evolutionary characteristics that describe the system. The basic indicators of security in the economy are the rate of GDP growth, the quality of life of the majority of the population, the rate of inflation, unemployment, economic structure, property division of the population, the position of the technical base of the economy, $\mathrm{R} \& \mathrm{~d}$ costs, competitiveness, dependence on imports, openness of the economy, domestic and foreign debt.

Threshold characteristics of socio-economic security - extreme indicators of these characteristics, non-compliance of which contributes to the deconstruction of the economy of the system-characteristics of homeostasis. They are used to describe the real situation of socioeconomic security and do not have all the chances to be comprehensive and functional for the system and other subsystems. Their volume is subject to the level of economic development, formed foundations, the true state of Affairs, the combination and composition of these characteristics. For example, state socio-economic security is compared with the state in which the degree of dependence of the country on the prevailing financial and economic group of States does not pass the line, threatening the loss of state independence, a significant remission of the economy, a tangible decrease in the standard of living of society or the failure of the strategic objectives of the state $[18$, p. 62]. As a quantitative boundary of the state economy's dependence on the global financial and economic system, the application of the maximum values of socio-economic security characteristics is proposed (Table 2). At the same time, the application of the differentiated value of this threshold is not simple, due to the fact that at the same time there is a significant number of conflicting criteria with a significant level of uncertainty and fuzziness. It is all the more difficult to provide differentiated values of this threshold for evaluation of possible results.

Measures to ensure socio-economic security - a meaningful everyday functioning of the subjects of socio-economic security, aimed at reflecting or blocking negative phenomena and processes in the socio-economic sphere. This work includes forecasting the dangers of socioeconomic security; determining the limits of the characteristics of socio-economic security; the creation of legislative acts to protect the socio-economic interests of society, the elimination of changes in the structure of the economy; maintaining a sufficient level of strategic resources of the country. The above has the opportunity to be considered as proposals on the results of modeling.

At the same time, the socio-economic formation of Belarus in the current circumstances cannot be considered without taking into account the policies of other States, the global trend, the activities of foreign economic entities and many other items that significantly affect the growth of the state's economy. As a result, it is necessary to consider a number of means that have all chances to limit or change the degree of influence of foreign entities on the Belarusian economy, primarily the policy of protectionism, taking into account the interests of the Belarusian socio-economic security.

At the current stage of formation of the economy and advanced market conditions, there are some questions, namely: how to implement the policy of protectionism, whether it is necessary in our country at this time and what are the positive and negative aspects of its use?

In order to answer correctly, you will need to realize the protectionism from within. Conventional definition: protectionism is a policy of defense of internal market from foreign competition through a system of restrictions: export and import duties, subsidies and other measures $[19$, p. 249]. As a method of purposeful management of the economy within the borders of the state, protectionism was formed at the beginning of the XV century and received the greatest recognition in the XVIII century. 
Table 2.

CRITICAL LIMITS OF THE DEVELOPMENT OF THE BELARUSIAN STATE AND SOCIETY

\begin{tabular}{|c|c|c|}
\hline The name of the indicator & $\begin{array}{c}\text { Critical } \\
\text { limits }\end{array}$ & Likely socio-economic impacts: \\
\hline Level of industrial production & $35 \%$ & The de-industrialization of the country \\
\hline Share of imported food & $35 \%$ & $\begin{array}{l}\text { Strategic dependence of the state on } \\
\text { imports }\end{array}$ \\
\hline Share in manufacturing exports & $40 \%$ & Raw material structure of the economy \\
\hline Share in exports of high-tech products & $15 \%$ & $\begin{array}{l}\text { Technological backwardness of the } \\
\text { economy }\end{array}$ \\
\hline Share of government spending on science in GDP & $2 \%$ & $\begin{array}{l}\text { Destruction of scientific and technological } \\
\text { potential }\end{array}$ \\
\hline Depreciation of fixed assets & $35 \%$ & Technogenic accident \\
\hline Income ratio of the richest $10 \%$ to the poorest $10 \%$ & 10:1 & Antagoniste social structure \\
\hline $\begin{array}{l}\text { Proportion of the population living below the poverty } \\
\text { line }\end{array}$ & $5 \%$ & Lumpenization of the population \\
\hline Ratio of minimum and average wages & $1: 3$ & $\begin{array}{l}\text { Dequalification and pauperization of the } \\
\text { workforce }\end{array}$ \\
\hline Unemployment rate & $10 \%$ & $\begin{array}{l}\text { Growth of socially disadvantaged } \\
\text { population }\end{array}$ \\
\hline Conditional depopulation rate & 1 & The excess of deaths over births \\
\hline Total fertility rate & 2,15 & $\begin{array}{l}\text { The lack of simple replacement of } \\
\text { generations }\end{array}$ \\
\hline Life expectancy, years & 85 & Reducing the viability of the country \\
\hline $\begin{array}{l}\text { Proportion of persons over } 65 \text { years of age to the } \\
\text { total population }\end{array}$ & $10 \%$ & The aging of the country \\
\hline Environmental safety costs, $\%$ of GDP & $2 \%$ & The threat of environmental disaster \\
\hline Environmental losses, \% of GDP & $5 \%$ & Environmental hazards \\
\hline Environmental costs & $2 \%$ & The degradation of the environment \\
\hline Number of crimes per 100000 people. & 5000 & Criminalization of social relations \\
\hline Level of alcohol consumption per person per year, 1 . & 7 & Physical degradation of the population \\
\hline Number of suicides per 100,000 population & 20 & Frustration of mass consciousness \\
\hline $\begin{array}{l}\text { Proportion of citizens advocating for a radical } \\
\text { change in the political system }\end{array}$ & $30 \%$ & Delegitimization of power \\
\hline Level of public confidence in Central authorities & $25 \%$ & Rejection of power by the people \\
\hline
\end{tabular}

Source: author's development [20].

Based on the modern perception of the essence of this method - the protection of the Belarusian manufacturer - we will answer the obvious question: is this tool of regulation and control of the economy still important?

In a market economy, protectionism and its policy carry with it the protection of its own producers, the preservation of the sales environment, the sales figure [21-22]. But this policy leads to the response of other States, it is possible to increase domestic tariffs due to the lack of competitors, the technical stupor of the production process, the maintenance of inefficient and inefficient economic entities in the economy. 
To sum up, the policy of protectionism in today's situation contains more negative than positive. Most likely, it is necessary to finish support of unprofitable economic entities which are considered a burden for formation of economy of the state, but whether it is necessary to disown from such means?

There is a logical question of social and economic security of the state: let's say, if all duties and fees were abolished, foreign economic entities and Belarusian producers would be in similar conditions, which would entail an increase in competition. Foreign manufacturers would be able to squeeze out the Belarusian manufacturer from the market. This is especially true of engineering, agriculture and a number of other sectors of the economy. This situation in the market would put the Republic of Belarus in a subordinate state to the products of foreign producers: first of all, it concerns the products of the 1st need, which implies the emergence of difficulties in ensuring food security of the state.

To sum up, although protectionism contains certain disadvantages, this policy is still weighty in some sectors of the Belarusian economy for the implementation of socio-economic security.

Considering the current financial and economic situation, it is possible to understand that our state is at a crossroads, and competitiveness is the very concept that opens up the whole problem of the tasks facing the government.

In today's world, it is impossible to completely isolate oneself from all the methods of taxes, contributions and duties, it is impossible to introduce a policy of protectionism in all sectors of the economy, it is impossible to stop the process of globalization. In addition, it is impossible to avoid the emergence of competition. In a market economy, the processes of reproduction of funds are associated with the struggle between producers for the field of activity, benefit and control over the market.

Taking into account the experience of taking measures to increase competitiveness, there are two leading vectors of the economy: the upper and lower paths.

The origin of these opinions refers to the history of the 2 vassals of Prince Charles (XVIII century), whom were imprisoned because their Lord unsuccessfully carried out the uprising. The first vassal was deprived of life, and the 2nd was released. Hen road means 'road of life' and low road means 'road of death'.

Mastering obsolete foreign technologies, attracting investment because of the low price of labor and the resale of natural resources at a low cost, the leakage of brains and money to the more developed countries-all this is characteristic of the lower way. The upper path includes the introduction of advanced technologies in production, increasing values for dramatically improved products, the inflow of brains and money [23, p. 78].

Summing up the above, we emphasize the need for optimal protectionism, maintaining competitiveness with a meaningful combination of market and government mechanisms of economic management. To date, it is essential to find its own niche in the international market economy, following the upper path of competitiveness.

\section{References:}

1. Kostin, V. I., \& Kostina, A. V. (2015). Natsional'naya bezopasnost' sovremennoi Rossii: ekonomicheskie i sotsiokul'turnye aspekty. Moscow, URSS, 344.

2. Porokhovskii, A. A. (2002). Vektor ekonomicheskogo razvitiya [Vector of economic development]. Moscow, Teis, 304.

3. Ignateva, M. V., \& Lipatova, L. N. (2014). Chelovecheskii potentsial ekonomicheskogo razvitiya: federal'nyi i regional'nyi aspekty. Regionologiya, (3), 127-134. 
4. Aizenshtadt, A. L., \& Akhramenko, P. G. (2014). Ekonomicheskaya sotsiologiya i sotsiologiya truda. Gomel, MITSO, 145.

5. Abalkin, L. I. (1997). Ekonomicheskaya bezopasnost' Rossii. Vestnik Rossiiskoi akademii nauk, 67(9), 771-776.

6. Avdiiskii, V. I. (2016). Ekonomicheskaya spravedlivost' i bezopasnost' ekonomicheskikh agentov. Moscow, Finansy i statistika, 271.

7. Grigoryan, S. A. (2016). Ekonomicheskaya spravedlivost' na mikro- i makrourovne v sovremennykh usloviyakh. Ekonomika i predprinimatel'stvo, (4/1), 1148-1152.

8. Guseva, V. I., Brovko, N. A., \& Sakharov, G. V. (2016). Sotsial'no-ekonomicheskaya sushchnost' bezopasnosti gosudarstva. Vestnik obrazovatel'nogo konsortsiuma. Ser.: Yurisprudentsiya, (4/1), 4-13.

9. Avramenko, A. I. (2013). Osnovnye faktory i ugrozy ekonomicheskoi bezopasnosti Respubliki Belarus. In: Teoriya $i$ praktika obespecheniya ekonomicheskoi bezopasnosti $v$ Respublike Belarus: materialy resp. nauch.-prakt. konf., Minsk, 14 dek. 2012 g. Minsk, 3-9.

10. Yaroshevich, V. I. (2015). Prakticheskie napravleniya obespecheniya mezhdunarodnoi konkurentosposobnosti otechestvennoi ekonomiki. Bankovskii vesnik, (4), 26-31.

11. Grunin, O. A., \& Grunin, S. O. (2002). Ekonomicheskaya bezopasnost' organizatsii. St. Petersburg, Piter, 160.

12. Savin, V. A. (1995). Nekotorye aspekty ekonomicheskoi bezopasnosti Rossii. Mezhdunarodnyi biznes Rossii, (9), 25-37.

13. Bendikov, M. A. (2000). Ekonomicheskaya bezopasnost' promyshlennogo predpriyatiya $\mathrm{v}$ usloviyakh krizisnogo razvitiya. Menedzhment $v$ Rossii i za rubezhom, (2).

14. Vidyapin, V. I. (1997). Osnovy ekonomicheskoi bezopasnosti: gosudarstvo, region, predpriyatie, lichnost'. Moscow, Intel-Sintez, 258.

15. Rubanov, V. A. (1994). Bezopasnost' Rossii v perekhodnyi period: metodologicheskii i politologicheskii analiz: Dr. diss. Moscow, 78.

16. Gusev, B. C. (1997). O nekotorykh aspektakh obespecheniya bezopasnosti kommercheskogo predpriyatiya v sovremennykh usloviyakh. In: Sovremennye problemy i metody sovershenstvovaniya upravleniya: sb. nauch. rabot. St. Petersburg, 34-36.

17. Shvaiba, D. (2019). Dynamic regression models of forecasting indicators of social and economic security. Bulletin of Science and Practice, 5(1), 249-257.

18. Sereda, V. N., \& Shevaleva, N. V. (2013). 'Osobye usloviya' v sisteme kriteriev natsional'noi bezopasnosti. Obozrevatel', (6), 59-72.

19. Sedova, M. L., Strokov, A. I., \& Chernov, A. Yu. (2014). Finansovoe regulirovanie sotsial'no-ekonomicheskikh protsessov. In: Finansy, Moscow, 246-275.

20. Shvaiba, D. (2018). Structural stability and socio-economic security of the hierarchical system. Bulletin of Science and Practice, 4(6), 233-239.

21. Subbotna, T. P. (2006). Rossiya na rasput'e: dva puti k mezhdunarodnoi konkurentosposobnosti. Voprosy ekonomiki, (2), 46-64.

22. Pravdin, A. (2014). Mozhet li Krym pozvolit' sebe nezavismost'? In: Krym, Telegraf, March 14, 12-13.

23. Tkachenko, A. (2016). Saimon Kuznets o demograficheskikh problemakh. Demograficheskoe obozrenie, 3(1), 71-93.

\section{Список литературы:}

1. Костин В. И., Костина А. В. Национальная безопасность современной России: экономические и социокультурные аспекты. M.: URSS, 2015. 344 с. 
2. Пороховский А. А. Вектор экономического развития. М.: Теис, 2002. 304 с.

3. Игнатьева М. В., Липатова Л. Н. Человеческий потенциал экономического развития: федеральный и региональный аспекты // Регионология. 2014. №3. С. 127-134.

4. Айзенштадт А. Л., Ахраменко П. Г. Экономическая социология и социология труда. Гомель: МИТСО, 2014. 145 с.

5. Абалкин Л. И. Экономическая безопасность России // Вестник Российской академии наук. 1997. Т. 67. №9. С. 771-776.

6. Авдийский В. И. Экономическая справедливость и безопасность экономических агентов. М.: Финансы и статистика, 2016. 271 с.

7. Григорян С. А. Экономическая справедливость на микро- и макроуровне в современных условиях // Экономика и предпринимательство. 2016. № 4/1. С. 1148-152.

8. Гусева В. И., Бровко Н. А., Сахаров Г. В. Социально-экономическая сущность безопасности государства // Вестник образовательного консорциума. Сер.: Юриспруденция. 2016. №4/1. С. 4-13.

9. Авраменко А. И. Основные факторы и угрозы экономической безопасности Республики Беларусь // Теория и практика обеспечения экономической безопасности в Республике Беларусь: материалы респ. науч.-практ. конф., Минск, 14 дек. 2012 г. Минск, 2013. C. 3-9.

10. Ярошевич B. И. Практические направления обеспечения международной конкурентоспособности отечественной экономики // Банковский весник. 2015. №4. С. 26-31.

11. Грунин О. А., Грунин С. О. Экономическая безопасность организации. СПб.: Питер, 2002. $160 \mathrm{c}$.

12. Савин В. А. Некоторые аспекты экономической безопасности России // Международный бизнес России. 1995. №9. С. 25-37.

13. Бендиков М. А. Экономическая безопасность промышленного предприятия в условиях кризисного развития // Менеджмент в России и за рубежом. 2000. №2.

14. Видяпин В. И. Основы экономической безопасности: государство, регион, предприятие, личность. М.: Интел-Синтез, 1997. 258 с.

15. Рубанов В. А. Безопасность России в переходный период: методологический и политологический анализ: дисс. ... д-ра политол. наук. М., 1994. 78 с.

16. Гусев В. С. О некоторых аспектах обеспечения безопасности коммерческого предприятия в современных условиях // Современные проблемы и методы совершенствования управления: сб. науч. работ. СПб., 1997. С. 34-36.

17. Shvaiba D. Dynamic regression models of forecasting indicators of social and economic security // Бюллетень науки и практики. 2019. Т. 5. №1. С. 249-257.

18. Середа В. Н., Шевалева Н. В. «Особые условия» в системе критериев национальной безопасности // Обозреватель. 2013. №6. С. 59-72.

19. Седова М. Л., Строков А. И., Чернов А. Ю. Финансовое регулирование социальноэкономических процессов // Финансы. М., 2014. С. 246-275.

20. Shvaiba D. Structural stability and socio-economic security of the hierarchical system // Бюллетень науки и практики. 2019. Т. 4. №6. С. 233-239.

21. Субботна Т. П. Россия на распутье: два пути к международной конкурентоспособности // Вопросы экономики. 2006. №2. С. 46-64.

22. Правдин А. Может ли Крым позволить себе независимость? // Крым: Телеграфъ. 2014. 14 марта. С. 12-13.

23. Ткаченко А. Саймон Кузнец о демографических проблемах // Демографическое обозрение. 2016. Т. 3. №1. С. 71-93. 


\section{Ссылка для циитирования:}

Shvaiba D. Analysis of the Components of Social and Economic Security and the Place of Protectionism in its Provision // Бюллетень науки и практики. 2019. Т. 5. №5. С. 291-300. https://doi.org/10.33619/2414-2948/42/38.

Cite as (APA):

Shvaiba, D. (2019). Analysis of the Components of Social and Economic Security and the Place of Protectionism in its Provision. Bulletin of Science and Practice, 5(5), 291-300. https://doi.org/10.33619/2414-2948/42/38. 